\title{
Intravenous insulin-like growth factor-I (IGF-I) in moderate-to-severe head injury: a Phase II safety and efficacy trial
}

Jimmi Hatton, Pharm.D., Robert P. Rapp, Pharm.D., Kenneth A. Kudsk, M.D., Rex O. Brown, Pharm.D., Mark S. Luer, Pharm.D., Julie G. Bukar, M.B.A., R.D., Sharon A. Chen, Ph.D., Craig J. McClain, M.D., Neil Gesundheit, M.D., Robert J. Dempsey, M.D., and Byron Young, M.D.

College of Pharmacy and the Departments of Surgery and Medicine, University of Kentucky Chandler Medical Center, Lexington, Kentucky; Department of Clinical Pharmacy, College of Pharmacy and Department of Surgery, College of Medicine, University of Tennessee at Memphis, Memphis, Tennessee; and Genentech, Inc., San Francisco, California

The purpose of this study was to determine the effect of insulin-like growth factor-I (IGF-I) on the catabolic state and clinical outcome of head-injured patients. Thirty-three patients between the ages of 18 and 59 years with isolated traumatic head injury and Glasgow Coma Scale (GCS) scores of 4 to 10 were randomized to one of two groups. All patients received standard neurosurgical intensive care plus aggressive nutritional support; the patients in the treatment group also received intravenous therapy with continuous IGF-I (0.01 mg/kg/hour).

During the 14-day dosing period, the control patients lost weight, whereas treated patients gained weight despite a significantly higher measured energy expenditure and lower caloric intake $(p=0.02)$. Daily glucose concentrations and nitrogen outputs were greater in control patients $(p=0.03)$ throughout the study period. During Week 1, only treated patients achieved positive nitrogen balance. Fifteen of 17 treated and 13 of 16 control patients survived the 1st week. No deaths occurred in patients whose serum IGF-I concentrations were higher than $350 \mathrm{ng} / \mathrm{ml}$. Dichotomized Glasgow Outcome Scale scores for patients with baseline GCS scores of 5 to 7 improved from poor to good for eight of 12 treated patients but for only three of 11 control patients $(p=0.06)$. Eight of 11 treated patients with serum IGF-I concentrations that were at least $350 \mathrm{ng} / \mathrm{ml}$ achieved moderate-to-good outcome scores at 6 months, compared to only one of five patients with lower concentrations $(\mathrm{p}<0.05)$. These findings indicate that pharmacological concentrations of IGF-I may improve clinical outcome and nitrogen utilization in patients with moderate-to-severe head injury.

Key Words * brain injury * insulin-like growth factor I * nitrogen balance * Glasgow Coma Scale * nutritional support * nutrition * treatment outcome

Patients suffering moderate-to-severe traumatic brain injury (TBI) demonstrate both hypermetabolism (increased energy expenditure) and hypercatabolism (increased protein loss) for up to several months after the insult.[14,24,47,63] Many investigators have found it difficult to achieve either positive caloric 
balance or positive nitrogen balance despite aggressive nutritional support.[14,24,47,63] When nutritional support is initiated early with aggressive administration of nonprotein calories, caloric balance is possible, but high nitrogen excretion rates and negative nitrogen balance persist. [6,13] The acute-phase response and hyperdynamic condition after head injury cannot be overcome with nutritional support alone.[14,43-45,61] The clinical consequences of inefficient nutrition after acute head injury include impaired immune function, delay in wound healing, muscle loss, and death.[51,52]

Pharmacological strategies to improve the use of nutrients during acute injury are under investigation.[21,35,50,59,60,66] Results with growth hormone have been inconsistent, depending on the severity of the injury and the timing of administration.[4,21,35,50,55,60,66] Insulin-like growth factor-I (IGF-I) is believed to mediate many of the anabolic effects of growth hormone.[10,31] Endogenous concentrations of IGF-I are depressed after brain injury.[27] Severe stress may induce a state of growth hormone resistance, leading to diminished synthesis of IGF-I in response to growth hormone; however, this finding has not been observed by all investigators. $[4,16,33,35]$

Insulin-like growth factor-I is a neurotrophic factor and has neuroprotective effects.[9,18,42,56] Higher endogenous concentrations of IGF-I are associated with improved survival after TBI.[27] Restoring IGF-I concentrations by administering recombinant human IGF-I (rhIGF-I) after TBI may benefit the patient's neurological response and may also have an effect on the patient's nitrogen balance. The purpose of this investigation was to determine the effect of rhIGF-I on the catabolic state and clinical outcome of patients who have suffered head injury.

\section{CLINICAL MATERIAL AND METHODS}

\section{Study Design and Patient Population}

This Phase II, open-label, prospective randomized trial was conducted at the University of Kentucky and the University of Tennessee at Memphis. The open-label design was requested by the United States Food and Drug Administration because IGF-I had not previously been administered to patients with TBI. Consecutively admitted patients between the ages of 18 and 59 years who had suffered traumatic head injury and had Glasgow Coma Scale[57] (GCS) scores of 4 to 10 were eligible. Patients were excluded for clinically significant disease or trauma other than head injury, chronic inflammatory diseases, spinal cord injury, diabetes, cancer, or uncontrolled seizures. Those treated by administration of more than 20 mg dexamethasone or its equivalent before randomization, those for whom death appeared to be imminent, and pregnant women were also excluded. After informed consent had been obtained, the patients were randomized on the basis of peak 6-hour postinjury GCS score, steroid dose, and age. All patients received standard neurosurgical intensive care combined with aggressive nutritional support as previously described;[64] the treatment group also received therapy with IGF-I. Intracranial pressure monitors were placed in all patients with GCS scores less than 8, according to routine neurotrauma care. This protocol was approved by the institutional review boards of both universities.

\section{Drug Administration/Monitoring}

Insulin-like growth factor-I was provided (Genentech, San Francisco, CA) as a sterile solution containing $5 \mathrm{mg}$ rhIGF-I/1 ml citrate/NaCl, $\mathrm{pH}$ 6. The IGF-I was administered by peripheral continuous intravenous infusion at $0.01 \mathrm{mg} / \mathrm{kg} / \mathrm{hour}$ beginning within 72 hours of injury and continuing for up to 14 days. During the 1st study day, pharmacokinetic sampling of blood was performed at baseline; at 5, 10, 15, 20, 30, 45, 60 , and 90 minutes; and at 2, 3, 4, 6, 12, and 24 hours after initiation of the infusion. Serum 
concentrations of IGF-I were determined every 24 hours on Days 2 through 13 . After the drug was discontinued, blood samples were collected at 0, 5, 10, 15, 20, 30, 45, and 60 minutes and at 2, 2.5, 3, and 4 hours for IGF-I quantification. Samples for determining serum concentrations of IGF-I and binding proteins were collected from control patients every morning. All assays were performed by Genentech.[38] Hematology, blood chemistry, urinalysis, creatinine clearance, partial thromboplastin time, and levels of prothrombin, free thyroxine $\left(\mathrm{T}_{4}\right)$, and thyroid-stimulating hormone were assessed regularly throughout the 14-day treatment period and at Day 28.

\section{Nutritional Support}

The goal of nutritional support was to provide nonprotein calories equal to 1.25 times the measured energy expenditure (MEE) plus $2 \mathrm{~g}$ protein $/ \mathrm{kg} /$ day for both groups. The MEE was determined by indirect calorimetry. Nonprotein calories were adjusted if the MEE changed by more than 500 calories. The route of nutritional support was not dictated by the protocol. Parenteral nutrition was used until bowel sounds returned and gastric residual volumes were less than $700 \mathrm{ml}$ in 24 hours. Lipid (Intralipid, 20\%) provided approximately $30 \%$ of nonprotein calories during administration of parenteral nutrition.

Energy expenditure in all patients was measured by indirect calorimetry at baseline and on study Days 2, $3,4,6,8,10,12$, and 15 . Twenty-four hour urine collections were obtained daily through Day 15 . Urinary concentrations of nitrogen and 3-methylhistidine $(3 \mathrm{MH})$ were analyzed according to their chemiluminescence. Patients were weighed on Days 1, 4, 7, 10, 13, and 15 and at follow-up periods. Anthropometric measurements (triceps skinfold and mid-arm circumference) were recorded on the same schedule as weight.

For patients receiving IGF-I, serum glucose was measured on Day 1 with each pharmacokinetic sample. After the 1st day, serum glucose was monitored by either finger stick or serum concentration every 6 hours. For the control group of patients, glucose monitoring was performed every 12 hours. Serum glucose concentrations were analyzed by using the hexokinase method. Insulin was administered according to a sliding scale protocol when glucose concentrations were greater than $200 \mathrm{mg} / \mathrm{dl}$. Hypoglycemia was defined as a serum glucose concentration of $70 \mathrm{mg} / \mathrm{dl}$ or less. Concentrations of C-peptide and insulin concentrations were measured by radioimmunoassay on Days 1 through 15 and on Day 28.

\section{Clinical Outcome}

Both GCS scores and intracranial pressures were recorded daily throughout the dosing period. All patients underwent follow-up examinations to assess nutritional and neurological outcome at Day 15, Day 30, the time of hospital discharge, and 3 months and 6 months after injury. Assessments of anthropometrics, weight, GCS score, and Glasgow Outcome Scale[34] (GOS) score were continued throughout this follow-up period.

\section{Statistical Analysis}

The metabolic endpoints examined during the study were MEE, nitrogen balance, serum glucose concentration, and urinary excretion of $3 \mathrm{MH}$. These variables were compared between groups by using repeated-measures analysis of covariance with age, GCS score, and prerandomization administration of steroids as covariates. The clinical endpoints were weight, anthropometrics, GCS score, and GOS score at Day 15, Day 28, and 3 months and 6 months postinjury. A linear mixed-effects model for an 
unbalanced repeated-measures design was used to compare mean responses between groups for these endpoints.

Calorie and nitrogen variables, laboratory changes, and IGF-I concentrations were compared by using paired and two-sample Student's t-tests. Analysis of documented infections and outcome scores was based on Fisher's exact test for sparse contingency tables and chi-square statistics. Statistical significance was set at $\mathrm{p}<0.05$.

\section{RESULTS}

\section{Patient Demographics}

At the two sites, a total of 33 patients were randomized. There were no significant differences in demographic data between the groups (Table 1). Steroids (<20 mg dexamethasone equivalent) were administered to two control patients and to one treated patient before randomization. One patient in the treatment group received $100 \mathrm{mg}$ methylprednisolone as a single dose on study Day 1 for the management of optic neuritis. Fourteen of 17 patients treated with IGF-I completed the 14-day course of therapy. Thirteen of the 16 control patients completed 14 days of the study. Two treated patients and three control patients died during the 14-day dosing period. Therapy was discontinued for a patient in the treatment group because of tachycardia accompanied by persistent agitation. These symptoms continued after discontinuation of the study drug and were not attributed to the IGF-I therapy. All patients received parenteral nutrition as the initial route for nutrition support. Transition to enteral nutrition was accomplished during the 14-day study course for 14 control patients and 13 IGF-I-treated patients. The length of parenteral nutrition compared to enteral nutrition was not different between the groups; most patients received a combination of each as the transition process was applied. The average length of hospital stay was approximately 42 days for survivors in both groups. 


\begin{tabular}{|c|c|c|}
\hline Factor & $\begin{array}{l}\text { Control Group } \\
\text { (16 patients) }\end{array}$ & $\begin{array}{l}\text { rhIGF-A-Treated } \\
\text { Group [1 } 17 \text { patients] }\end{array}$ \\
\hline \multicolumn{3}{|l|}{ gender (ino of patients) } \\
\hline female & 2 & 3 \\
\hline male & 14 & 14 \\
\hline \multicolumn{3}{|l|}{ age (urs) } \\
\hline mean (SD) & $27.8(9.21)$ & $27.6(7.7)$ \\
\hline median & 24 & 27 \\
\hline range & $18-46$ & $18-40$ \\
\hline \multicolumn{3}{|l|}{ weight at baseline examination ( $k g$ ) } \\
\hline mean (SD) & $75.7(14.89)$ & $71.3(12.22)$ \\
\hline median & 71.1 & 68.5 \\
\hline range & $61-115$ & $53-100$ \\
\hline \multicolumn{3}{|l|}{ baseline GCS score ${ }^{x}$} \\
\hline mean (SD) & $6.1(2.16)$ & $7(2.25)$ \\
\hline median & 6 & 7 \\
\hline range & $3-10$ & $4-12$ \\
\hline \multicolumn{3}{|l|}{ type of head injury (no. of patients) } \\
\hline closed head injury & 8 & 11 \\
\hline skull fracture & 4 & 2 \\
\hline subdural hematoma. & 2 & 0 \\
\hline epidural hematoma & 3 & 2 \\
\hline in traceretral hematoma & 1 & 1 \\
\hline in tracranial missile & 1 & 2 \\
\hline \multicolumn{3}{|l|}{ elapsed time to treatment (hrs) } \\
\hline mean (SD) & $57.1(8.52)$ & $56.5(9.91)$ \\
\hline median & 54.5 & 54 \\
\hline range & $41-73$ & $44-73$ \\
\hline \multicolumn{3}{|l|}{ time on wentilator (days) } \\
\hline mean (SD) & $11.4(5.29)$ & $11.2(5.86)$ \\
\hline median & 14.5 & 16 \\
\hline range & $3-16$ & $3-16$ \\
\hline
\end{tabular}

Clinical events are summarized in Table 2. No serious life-threatening event was attributed to IGF-I treatment. Patients received standard care for neurosurgical intensive care patients, including courses of antibiotic medications, anticonvulsant agents when required, mannitol, diuretics, and histamine antagonists. No treatment differences were noted between the groups. No differences in vital signs, hematological analyses, or blood chemistry were noted between the groups. Pretreatment free $\mathrm{T}_{4}$ values were within normal limits in both groups. Total pretreatment $\mathrm{T}_{4}$ values were reduced in six of 16 control patients and in nine of 17 IGF-I-treated patients. Pretreatment thyroid-stimulating hormone values were reduced in three treated patients and four control patients. These values returned to normal limits at Day 15 , with the exception of total $\mathrm{T}_{4}$ in one IGF-I-treated patient. 


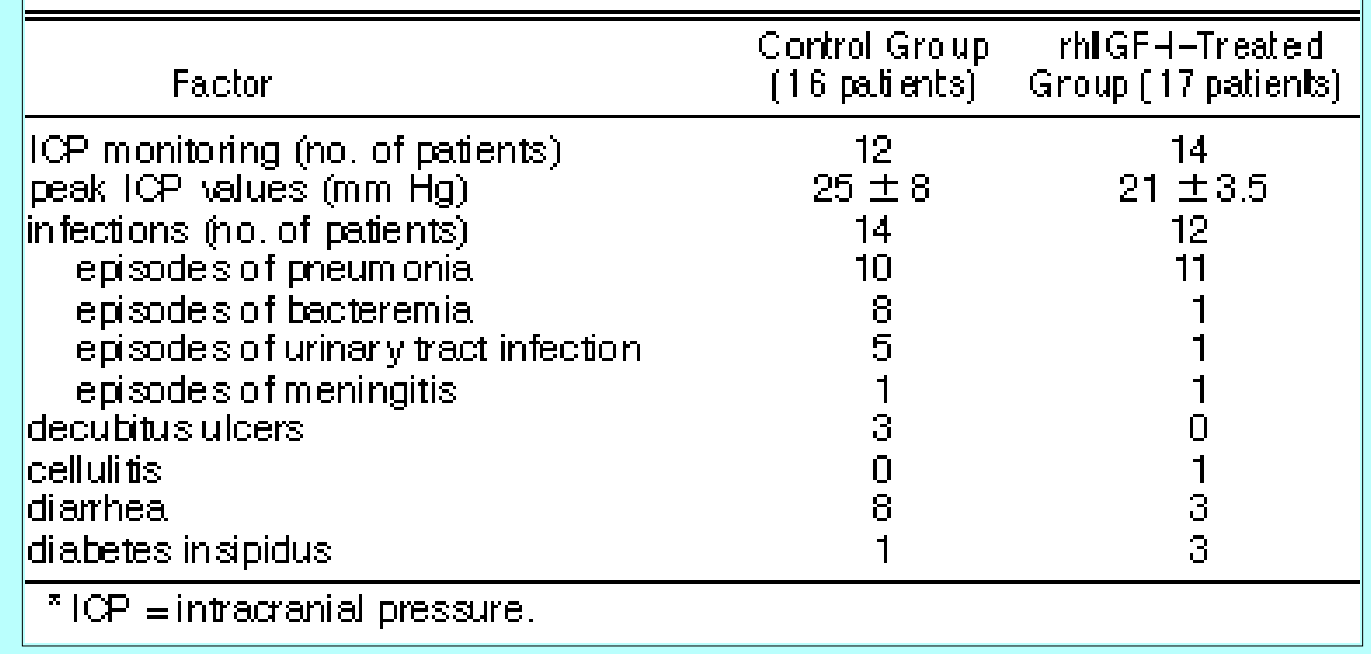

\section{Nutritional Outcome}

Energy Expenditure. Baseline MEEs were $2381 \pm 369 \mathrm{kcal} /$ day (mean \pm standard deviation [SD]) in control patients and $2562 \pm 586 \mathrm{kcal} / \mathrm{day}$ in the treated group. These baseline energy expenditures were from 1 to 1.6 times the predicted energy expenditure in control patients and from 1.1 to 2 times that in treated patients.[32] Overall, control patients had a lower MEE $(\mathrm{p}=0.01)$ and higher caloric intake $(\mathrm{p}=$ 0.02 ) than patients treated with IGF-I (Fig. 1). The overall average caloric intake was $40 \mathrm{kcal} / \mathrm{kg} /$ day in control patients and $36 \mathrm{kcal} / \mathrm{kg} / \mathrm{day}$ in treated patients. Caloric balance (nonprotein intake minus MEE) was significantly different between the groups (Fig. 1). During both weeks, the control patients had a more positive caloric balance than the treated patients $(\mathrm{p}=0.04)$.

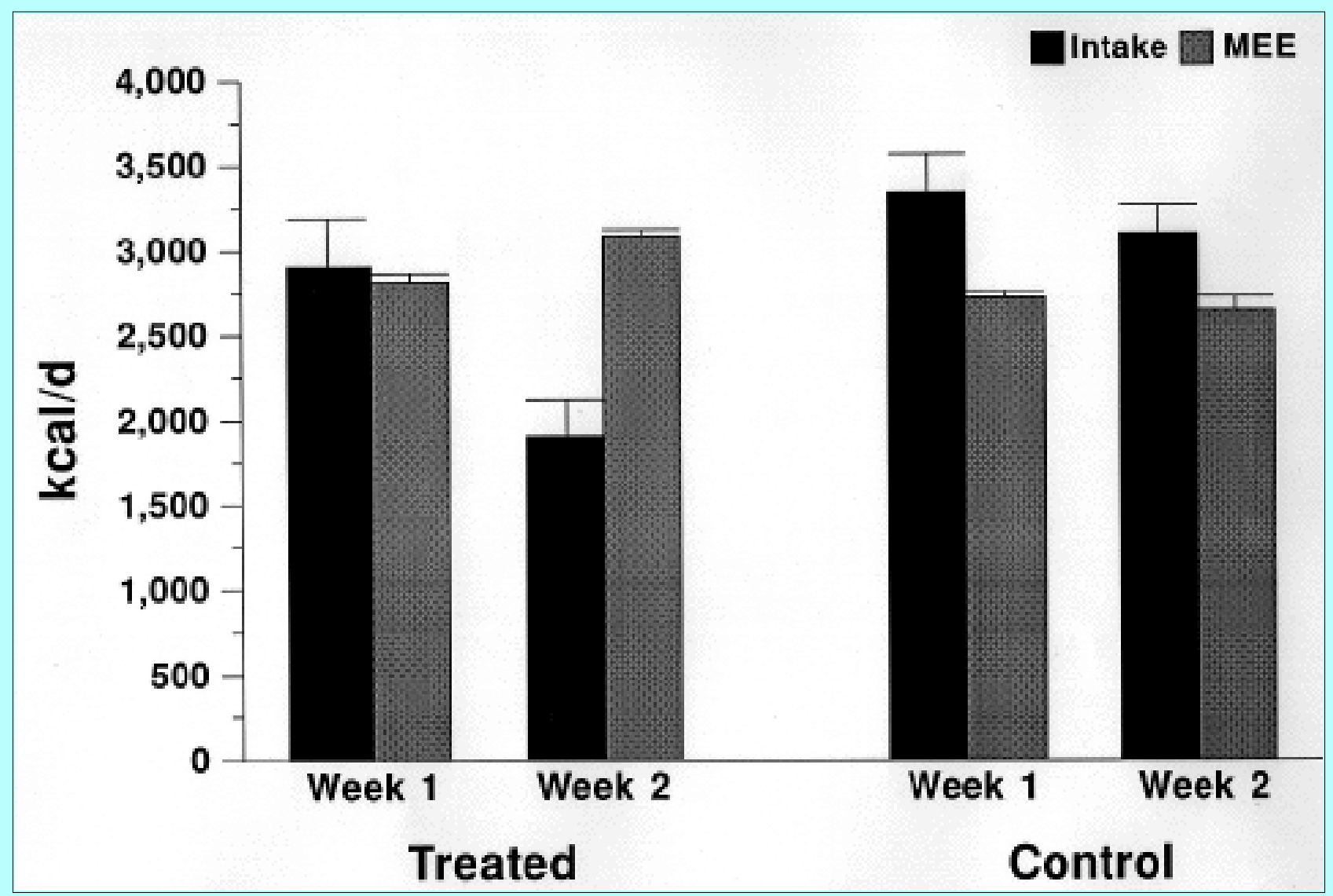


Fig. 1. Bar graph displaying calorie intake and MEE in control and IGF-I-treated patients. Nonprotein calorie intake was greater in the control group $(3260 \pm 229 \mathrm{kcal} /$ day [d]) than in the group treated with IGF-I $(2576 \pm 560 \mathrm{kcal} / \mathrm{d} ; \mathrm{p}=0.02)$. Measured energy expenditure was higher in the IGF-I group $(2908 \pm 149 \mathrm{kcal} / \mathrm{d})$ than in the control group $(2700 \pm 52$ $\mathrm{kcal} / \mathrm{d} ; \mathrm{p}=0.01$ ).

Nitrogen. The overall mean protein intake was $1.8 \pm 0.14 \mathrm{~g} / \mathrm{kg} /$ day in control patients and $1.6 \pm 0.35$ $\mathrm{g} / \mathrm{kg} / \mathrm{day}$ in treated patients. Nitrogen intake during Week 1 was not significantly different between the groups; however, during Week 2 , intake in the treated group was significantly less than that in the control group ( $p=0.002)$ (Fig. 2). Nitrogen output in the control group was greater than that of the treated group during both study weeks $(\mathrm{p}=0.04)$. The treated group achieved a positive mean nitrogen balance during Week 1 (Fig. 3), but the control group did not. Although nitrogen output was lower in treated patients during Week 2, nitrogen balance was negative in both groups during Week 2 . There was no significant difference in $3 \mathrm{MH}$ excretion between groups.

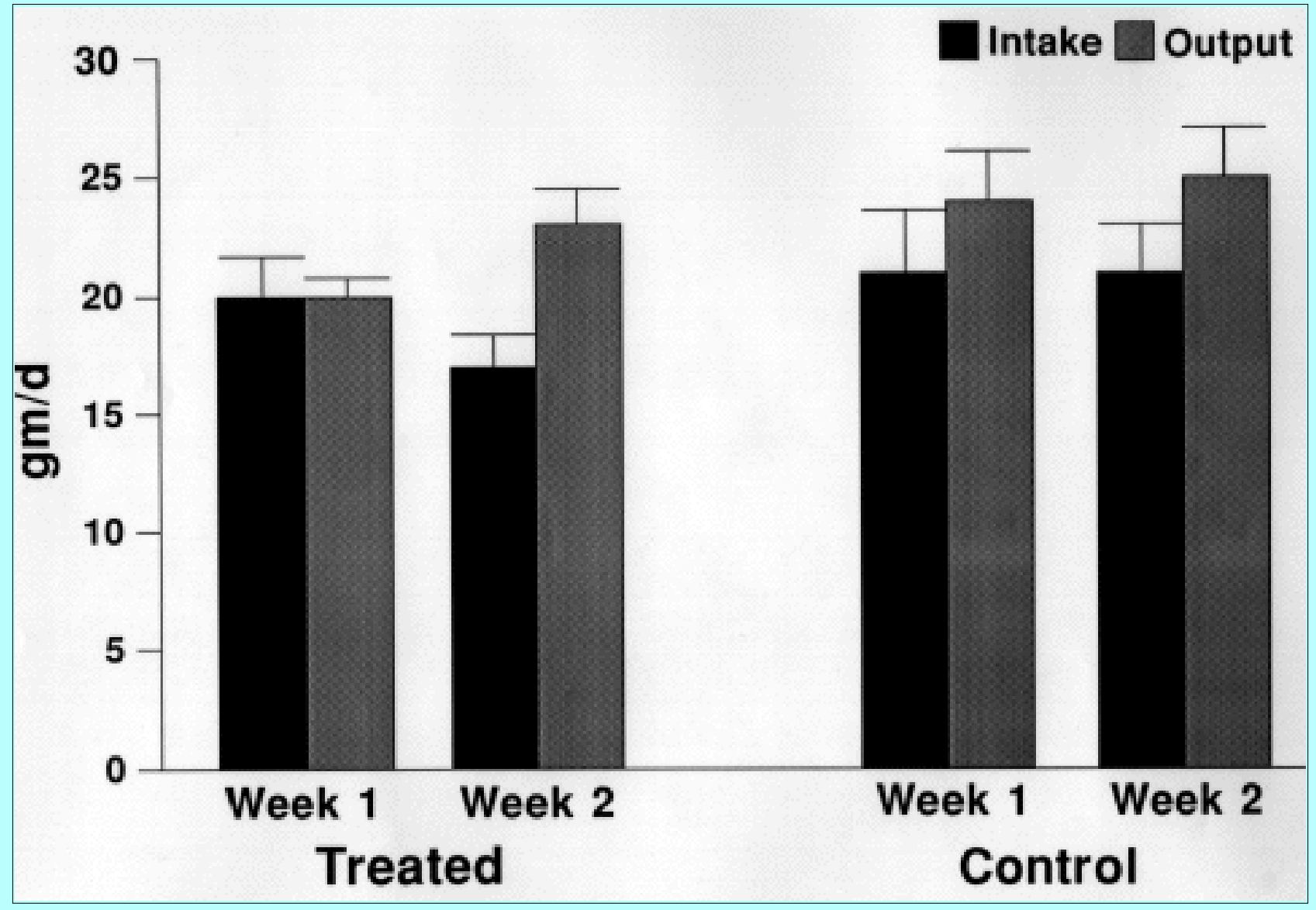

Fig. 2. Bar graph showing nitrogen input and output in head-injured patients. Nitrogen intake was not different between the two groups during Week 1 (control group $21 \pm 2.6$ g/day [d] vs. treated group $20 \pm 1.7 \mathrm{~g} / \mathrm{d}$ ). During Week 2, nitrogen intake was significantly lower in the IGF-I-treated group (control group $21 \pm 2 \mathrm{~g} / \mathrm{d}$ vs. treated group $17.3 \pm 1.4 \mathrm{~g} / \mathrm{d}$; $\mathrm{p}$ $=0.002$ ). Nitrogen output was higher in control patients in Week 1 (control group $25 \pm 2.1$ $\mathrm{g} / \mathrm{d}$ vs. treated group $20 \pm 0.8 \mathrm{~g} / \mathrm{d} ; \mathrm{p}=0.004$ ). During Week 2, nitrogen output increased in the IGF-I-treated group but remained lower than that in the control patients (control group $25 \pm 2.3 \mathrm{~g} / \mathrm{d}$ vs. treated group $23 \pm 1.5 \mathrm{~g} / \mathrm{d} ; \mathrm{p}=0.04$ ).

Weight. Despite improved caloric balance and higher nitrogen intake, the weight of control patients had 
decreased by $2.8 \pm 11.1 \%$ at Day 15 . Conversely, at the same time point, the weight of treated patients had increased by $2.3 \pm 8.9 \%$ above admission weights. Anthropometric values did not differ significantly between the groups.

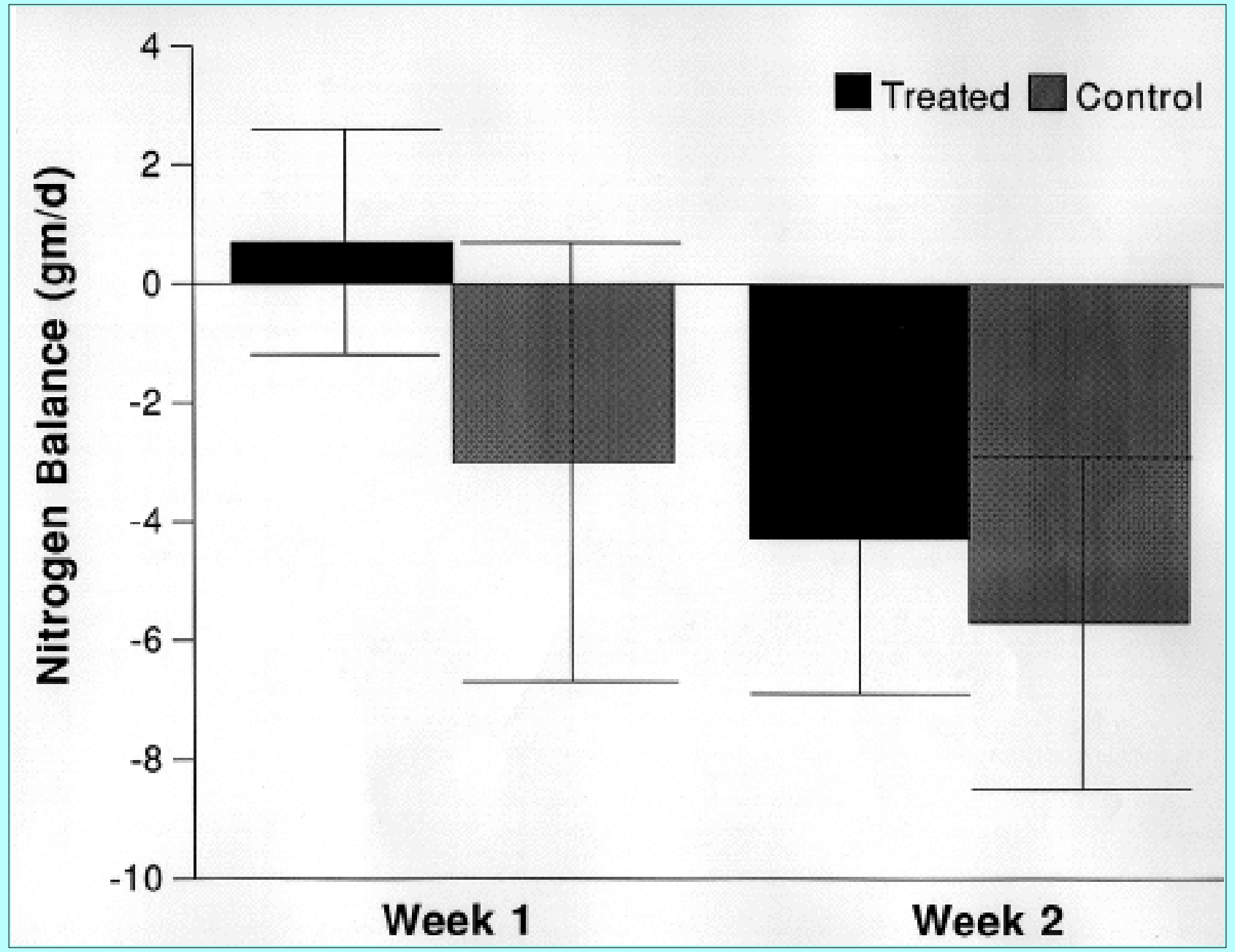

Fig. 3. Bar graph showing nitrogen balance in head-injured patients. Nitrogen balance was significantly more positive in the IGF-I-treated group during Week 1 (treated group $0.7 \pm$ $1.9 \mathrm{~g}$ vs. control group $-3 \pm 3.7 \mathrm{~g} ; \mathrm{p}=0.04$ ). During Week 2 , nitrogen balance was not significantly different (control group $-5.7 \pm 2.8 \mathrm{~g}$ vs. treated group $-4.3 \pm 2.6 \mathrm{~g}$ ).

Glucose. Average daily glucose concentrations were higher among control patients $(179 \pm 21 \mathrm{mg} / \mathrm{dl})$ than among treated patients $(146 \pm 12 \mathrm{mg} / \mathrm{dl})$ throughout the protocol $(\mathrm{p}=0.03)$. One patient in the control group required treatment for a glucose concentration of $63 \mathrm{mg} / \mathrm{dl}$ on Day 13 during transition to enteral feeding. Similarly, two IGF-I-treated patients received a dextrose bolus on Day 13 while receiving enteral nutrition. Patients had no symptoms of hypoglycemia; low blood sugar concentrations were identified by protocol-driven glucose monitoring. Serum insulin concentrations were elevated in both groups. There was no difference in insulin dose or in the number of patients treated with insulin between the groups. The C-peptide values were increased for all patients in both groups, but the differences were not statistically significant.

\section{Serum IGF-I Concentrations}

At baseline, endogenous serum IGF-I concentrations were below reported physiological concentrations (150-400 ng/ml) for all patients (Fig. 4).[31] Concentrations of IGF-I above $150 \mathrm{ng} / \mathrm{ml}$ were achieved for 
all treated patients but for only six control patients $(\mathrm{p}<0.01)$. Physiological concentrations were restored for all treated patients within the first 24 hours of dosing. The average time for restoration of physiological levels in the control group was significantly delayed to $7 \pm 4.5$ days $(\mathrm{p}<0.01)$.

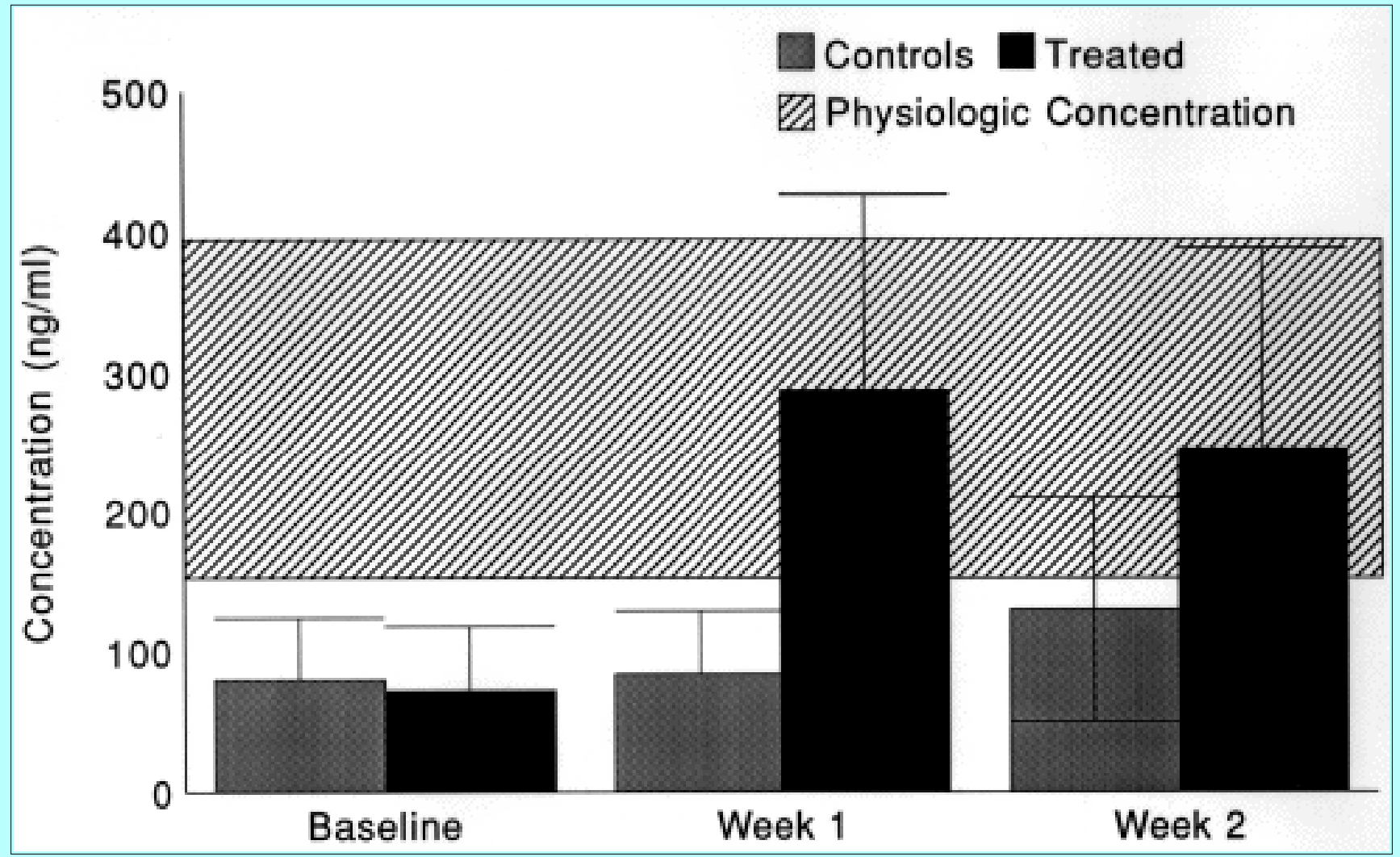

Fig. 4. Bar graph showing serum concentrations of IGF-I from baseline through the second week of treatment. Serum concentrations of IGF-I were depressed below $150 \mathrm{ng} / \mathrm{ml}$ after TBI. Administration of IGF-I restored physiological concentrations within 24 hours of dosing. The average concentration of IGF-I in Week 1 was $85 \pm 45 \mathrm{ng} / \mathrm{ml}$ in the control group and $288 \pm 138.5 \mathrm{ng} / \mathrm{ml}$ in the treated group $(\mathrm{p}=0.001)$. During the $2 \mathrm{nd}$ week after injury, the control patients had an average serum concentration of $130 \pm 79.5 \mathrm{ng} / \mathrm{ml}$, compared to $246 \pm 143 \mathrm{ng} / \mathrm{ml}$ in the treated group $(\mathrm{p}=0.02)$.

The average IGF-I concentrations at Week 1 and Week 2 in the control group were significantly lower than that of the IGF-I-treated group (Fig. 4; $p=0.0001$ at Week $1 ; p=0.02$ at Week 2). The average peak concentration for IGF-I-treated patients was $458 \pm 178 \mathrm{ng} / \mathrm{ml}$, compared with $156 \pm 99.7 \mathrm{ng} / \mathrm{ml}$ for control patients $(\mathrm{p}<0.01)$. The time to peak concentration was $4 \pm 2.3$ days for treated patients, compared to $11 \pm 4.5$ days for control patients ( $\mathrm{p}<0.01$ ). For 13 IGF-I-treated patients, IGF binding protein (BP)-3 concentrations decreased from $2.8 \pm 0.2$ to $2.1 \pm 0.2 \mathrm{mg} / \mathrm{dl}$. Concentrations of IGFBP-2 increased from $275 \pm 46 \mu \mathrm{g} / \mathrm{ml}$ to $678 \pm 145 \mu \mathrm{g} / \mathrm{ml}$ over the 14-day period. Plasma growth hormone concentrations declined from $2.3 \pm 0.6 \mu \mathrm{g} / \mathrm{L}$ to $0.4 \pm 0.1 \mu \mathrm{g} / \mathrm{L}$.

Serum IGF-I concentrations of $350 \mathrm{ng} / \mathrm{ml}$ were reached for 11 treated patients during the study; for eight of these patients, this level was achieved during the first 24 hours of infusion. Despite continuous drug administration, serum IGF-I concentrations greater than $350 \mathrm{ng} / \mathrm{ml}$ were maintained only for an average of $7.5 \pm 3.8$ days. For six treated patients, serum IGF-I concentrations did not reach peaks greater than $350 \mathrm{ng} / \mathrm{ml}$ at any point in the dosing period; two of these treated patients and three control patients died within the 1st week of injury. The baseline predose concentration of IGF-I was higher for patients whose 
serum IGF-I concentrations were above $350 \mathrm{ng} / \mathrm{ml}$ during the infusion $(80 \pm 50 \mathrm{ng} / \mathrm{ml} \mathrm{vs.} 40 \pm 8.9 \mathrm{ng} / \mathrm{ml}$, $\mathrm{p}<0.05)$.

\section{Neurological Outcome}

After randomization, the 6-hour postinjury score of one patient had improved to 12 before dosing; data from this patient are not included in the neurological outcome analysis. Three deaths occurred in the treated group and five in the control group. Within the 1st week, two patients in the IGF-I-treated group and three in the control group died. Early deaths were due to severe brain injury in three cases, sepsis in one case, and multiple organ dysfunction syndrome in one other case. A favorable outcome trend was observed for treated patients surviving the 1st week after injury with GCS scores of 5 to 7 (Fig. 5). Dichotomized GOS scores improved from poor to good for eight (67\%) of 12 treated patients, compared to three $(27 \%)$ of 11 control patients $(\mathrm{p}=0.06)$.

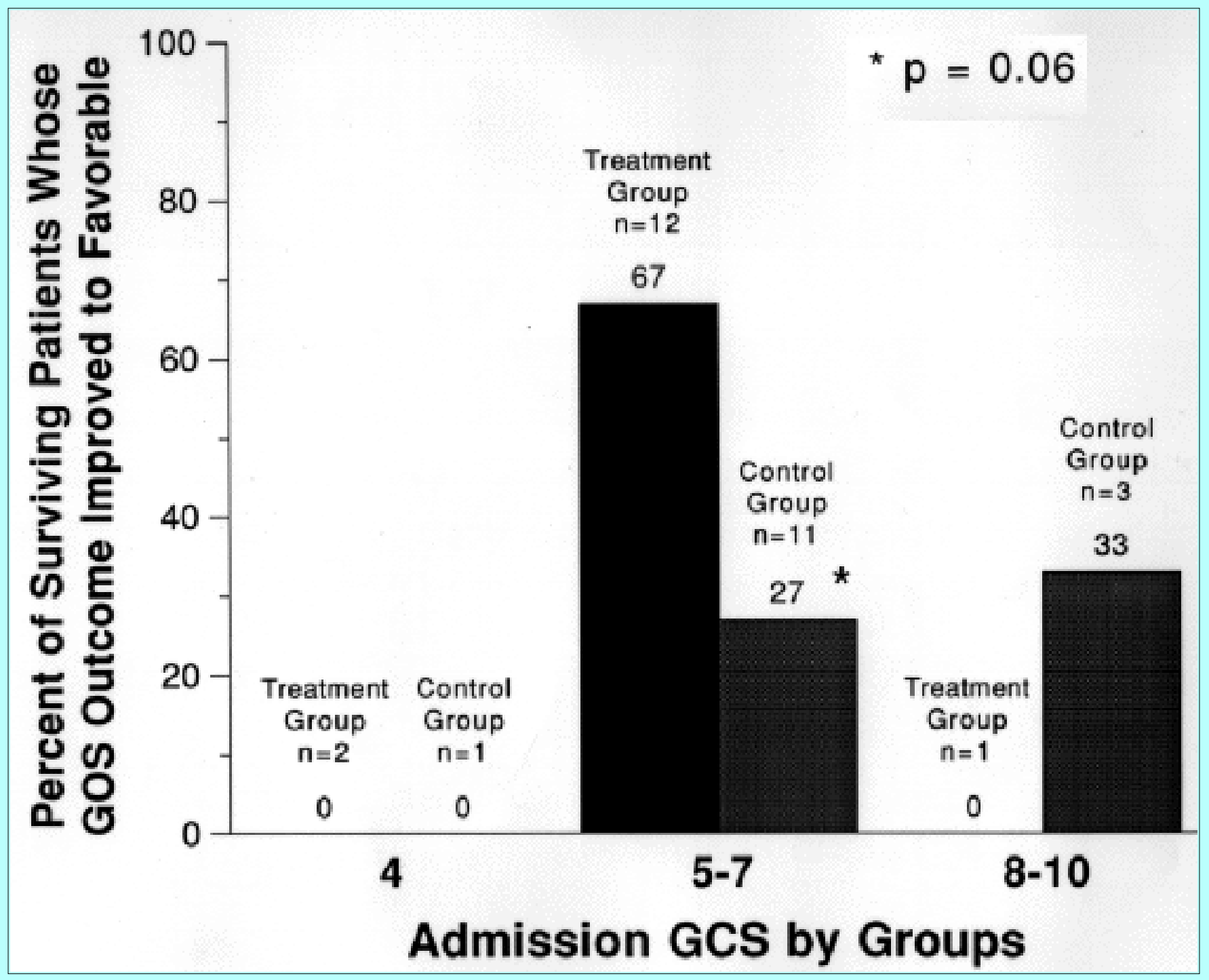

Fig. 5. Bar graph showing patient outcome as it relates to admission GCS score. All surviving patients admitted with a GCS score of 4 remained vegetative or severely disabled (according to GOS scores). For eight patients in the treated group and three patients in the control group admitted with GCS scores of 5 through 7, GOS scores improved from poor outcome at Day 15 to moderate disability or good recovery $(\mathrm{p}=0.06)$. Patients with admission GCS scores of 8 through 10 had 15-day GOS scores of good, except for one of the control patients whose GOS score improved from vegetative to good recovery at 6 
months.

The effect of serum IGF-I concentration on the outcome of patients was evaluated. Baseline IGF-I concentrations were not significantly different between survivors $(84 \pm 48 \mathrm{ng} / \mathrm{ml})$ and nonsurvivors $(55 \pm$ $32 \mathrm{ng} / \mathrm{ml})$. No deaths were reported among the 11 patients who achieved serum IGF-I concentrations greater than $350 \mathrm{ng} / \mathrm{ml}$, compared with three deaths among the five patients who did not achieve this concentration $(\mathrm{p}=0.02)$. In the treated group, eight of 11 patients with serum IGF-I concentrations greater than $350 \mathrm{ng} / \mathrm{ml}$ achieved moderate-to-good outcome scores at 6 months, compared with only one of five patients with lower concentrations $(\mathrm{p}<0.05)$.

\section{DISCUSSION}

Head-injured patients treated with IGF-I gained weight and retained nitrogen despite a negative caloric balance and lower nitrogen intake. Previous investigations have demonstrated hypercatabolism and protein loss to be unresponsive despite protein replacement at doses up to $2.5 \mathrm{~g} / \mathrm{kg} /$ day for severely stressed patients. $[6,13,63]$ Low IGF-I concentrations may contribute to the inefficient use of exogenous protein after head injury.[12,46] All head-injured patients had depressed baseline IGF-I concentrations, and these depressed concentrations persisted for approximately 7 days in the control group. In contrast, administration of IGF-I restored serum concentrations to at least $150 \mathrm{ng} / \mathrm{ml}$ for all treated patients within the first 24 hours of dosing. Improved nitrogen balance occurred when IGF-I concentrations were restored to the physiological range. In the current study, the control patients had greater nitrogen output over the study period than the treated patients, despite higher protein intake. Nitrogen retention appeared to be more efficient in the treatment group. The poor caloric intake may have limited the efficacy of IGF-I during the 2nd week; however, low nitrogen intake makes it difficult to interpret this finding conclusively.[12,46]

Nutritional support has not been effective in reducing nitrogen excretion after TBI.[6,58,64] Therapeutic strategies for overriding the catabolic state have been tried in a variety of populations.[21,35,50,59,60,66] Growth hormone has successfully reduced urinary nitrogen loss in both surgically treated and burn populations.[21,35,50,60,66] This effect of growth hormone was not observed after multiple trauma.[4,55] The variability in growth hormone response after TBI, combined with the side effects of hyperglycemia and fluid retention, may limit its potential for use in traumatic brain injury.[10,37]

Insulin-like growth factor-I mediates many of the anabolic effects of growth hormone.[22,31] Within the liver, the binding of growth hormone to receptors initiates the production of IGF-I and its associated binding proteins.[31] This process is dependent on adequate nutritional intake.[31,46] The IGF-I acts both systemically and locally to suppress protein degradation, increase amino acid uptake, and increase cellular proliferation and differentiation.[22] Severe stress and acute disease alter normal patterns of increased IGF-I in response to nutrients.[8,33] When serum concentrations were increased by administration of systemic IGF-I therapy, protein oxidation was reduced after acute thermal injury.[11] Similarly, when physiological concentrations of IGF-I were restored in our head-injured patients receiving IGF-I, nitrogen excretion was lower than that in the control group. The association of reduced nitrogen excretion with IGF-I therapy deserves additional research.

The hypoglycemic effect of IGF-I may be particularly attractive during administration of specialized nutritional support. Previous investigations of TBI have demonstrated higher mortality rates when patients were significantly underfed.[52] Improved neurological outcome was seen when adequate 
nutritional support was implemented early.[64] Although nutrition protocols were standardized and initiated early in our study, nutrient intake was lower in the treated group. Despite the compromise in intake, the positive trends continued in the treatment group.

The glucose-modulating properties of IGF-I may contribute to its potential beneficial effect in the treatment of patients with TBI. Hyperglycemia is common after TBI and is associated with poor outcome. $[40,54,62]$ The hypoglycemic potential of IGF-I could contribute to a neurological benefit for patients with TBI.[29] Serum glucose concentrations were significantly lower among our patients treated with IGF-I. This clinical response is similar to observations among other IGF-I-treated populations, but the difference in caloric intake may also have contributed to this observation.

Concentrations of IGF-I may influence mortality after TBI.[27] Gottardis, et al.,[27] observed that patients with TBI who died had lower IGF-I concentrations than survivors. In our study, admission IGF-I concentrations did not predict survival for our patients. However, rapid restoration of physiological IGF-I concentrations for the treated group may explain the different clinical outcomes. The significant difference in the number of deaths between treated patients with IGF-I concentrations above $350 \mathrm{ng} / \mathrm{ml}$ and those with lower concentrations suggests that more definitive studies are needed.

Treated patients with admission GCS[57] scores of 5 to 7 who survived the initial week after injury had improved neurological outcomes compared with similar patients in the control group. In the treated group, patients with serum concentrations exceeding $350 \mathrm{ng} / \mathrm{ml}$ during the dosing phase had a greater improvement in neurological outcome scores at 6 months. The concentration of $350 \mathrm{ng} / \mathrm{ml}$ is near the upper limit of reported normal values and may indicate a minimum concentration for therapeutic efficacy. The full extent of the effects of IGF-I at higher concentrations for extended periods is not known.

Despite continuous infusion, serum concentrations greater than $350 \mathrm{ng} / \mathrm{ml}$ could not be maintained throughout the 14-day dosing period. A change in IGF-I clearance would be consistent with the negative feedback of IGF-I on growth hormone secretion.[5] A decrease in growth hormone alters the production of IGFBP-3, the principal binding protein that prolongs the systemic half-life of IGF-I.[3,5,7] A lower concentration of IGFBP-3, as a result of lower production of endogenous growth hormone, reduces the half-life of IGF-I from approximately 18 hours to only 8 minutes.[30] We measured IGFBP-3, IGFBP-2, and growth hormone in 13 of our IGF-I-treated patients. A decline in IGFBP-3 was observed and found to be associated with falling IGF-I concentrations and rising IGFBP-2 concentrations. [7] Growth hormone concentrations also decreased during IGF-I treatment.[7] Dosing strategies to override this effect will be needed if the relationship of IGF-I concentrations and neurological improvement is to be more definitively evaluated.

Higher serum concentrations may improve bioavailability to the injured brain. Insulin-like growth factor-I receptors have been found throughout the brain and persist throughout the aging process.[1,2,15,17] Separate receptors for IGF-I have been isolated on brain capillaries.[23] The maximum binding of the IGF receptor is approximately fivefold greater than that for the blood-brain barrier insulin receptor.[49] The IGF-I is internalized by isolated brain capillaries, suggesting the presence of a transport system. These findings lead one to speculate that circulating IGF-I may be transported into the brain via these existing systems.

Insulin-like growth factor-I is a growth factor present within the central nervous system.[53] Both neurological and neuroprotective properties have been attributed to IGF-I.[9,18,28,42,56] An increased 
expression of IGF-I within the central nervous system has been demonstrated after brain injury.[25] Intraventricular administration of IGF-I in a hypoxic-ischemic animal model reduced central nervous system neuronal loss by more than $80 \%$.[26] Therefore, several factors could be responsible for neurological improvement after the administration of IGF-I.

\section{CONCLUSIONS}

Several promising investigational therapies have failed to produce improved outcome once tested in large, multicenter trials. $[19,20,36,41,48,65]$ Additional research will be needed to evaluate the potential of IGF-I as a therapeutic agent for patients with head injury. In this small pilot study, significant trends in improved outcome and nutritional response were observed despite the limitation in population size and difference in nutrient intakes. Modified dosing strategies should be tested for a larger population of patients with TBI to clarify the potential of IGF-I for improving neurological outcome. Evidence from normal volunteers and cachectic patients with acquired immune deficiency indicates that growth hormone-dependent binding proteins need to be restored along with IGF-I to optimize serum concentrations and promote anabolism.[36,39] Defining optimal serum and cerebrospinal fluid concentrations and determining a dosing strategy for maintaining those concentrations will be the goals of further investigations using this therapy.

\section{References}

1. Aguado F, Sánchez-Franco F, Rodrigo J, et al: Insulin-like growth factor I-immunoreactive peptide in adult human cerebellar Purkinje cells: co-localization with low-affinity nerve growth factor receptor. Neuroscience 59:641-650, 1994

2. Armstrong RC, Dorn HH, Kufta CV, et al: Pre-oligodendrocytes from adult human CNS. J Neurosci 12:1538-1547, 1992

3. Baxter RC: Physiological roles of IGF binding proteins, in Spencer EM (ed): Modern Concepts of Insulin-like Growth Factors. Proceedings of the Second International Symposium on Insulin-Like Growth Factors/Somatomedins held January 12-16, 1991, in San Francisco, California. New York: Elsevier, 1991, pp 371-379

4. Behrman SW, Kudsk KA, Brown RO, et al: The effect of growth hormone on nutritional markers in enterally fed immobilized trauma patients. JPEN J Parenter Enteral Nutr 19:41-46, 1995

5. Bermann M, Jaffe CA, Tsai W, et al: Negative feedback regulation of pulsatile growth hormone secretion by insulin-like growth factor I. Involvement of hypothalamic somatostatin. J Clin Invest 94:138-145, 1994

6. Bivins BA, Twyman DL, Young AB: Failure of nonprotein calories to mediate protein conservation in brain-injured patients. J Trauma 26:980-986, 1986

7. Blum WR, Ranke MB: Insulin-like growth factor binding proteins (IGFBPs) with special reference to IGFBP-3. Acta Paediatr Scand Suppl 367:55-62, 1990

8. Buonpane EA, Brown RO, Boucher BA, et al: Use of fibronectin and somatomedin-C as nutritional markers in the enteral nutrition support of traumatized patients. Crit Care Med 17:126-132, 1989 
9. Cheng B, Mattson MP: IGF-I and IGF-II protect cultured hippocampal and septal neurons against calcium-mediated hypoglycemic damage. J Neurosci 12:1558-1566, 1992

10. Chwals WJ, Bistrian BR: Role of exogenous growth hormone and insulin-like growth factor I in malnutrition and acute metabolic stress: a hypothesis. Crit Care Med 19:1317-1322, 1991

11. Cioffi WG, Gore DC, Rue LW III, et al: Insulin-like growth factor-1 lowers protein oxidation in patients with thermal injury. Ann Surg 220:310-319, 1994

12. Clemmons DR, Smith-Banks A, Underwood LE: Reversal of diet-induced catabolism by infusion of recombinant insulin-like growth factor-I in humans. J Clin Endocrinol Metab 75:234-238, 1992

13. Clifton GL, Robertson CS, Choi SC: Assessment of nutritional requirements of head-injured patients. J Neurosurg 64:895-901, 1986

14. Clifton GL, Robertson CS, Grossman RG, et al: The metabolic response to severe head injury. J Neurosurg 60:687-696, 1984

15. Crews FT, McElhaney R, Freund G, et al: Insulin-like growth factor I receptor binding in brains of Alzheimer's and alcoholic patients. J Neurochem 58:1205-1210, 1992

16. Dahn MS, Lange MP, Jacobs LA: Insulinlike growth factor 1 production is inhibited in human sepsis. Arch Surg 123:1409-1414, 1988

17. De Keyser J, Wilczak N, Goossens A: Insulin-like growth factor-I receptor densities in human frontal cortex and white matter during aging, in Alzheimer's disease, and in Huntington's disease. Neurosci Lett 172:93-96, 1994

18. D'Mello SR, Galli C, Ciotti T, et al: Induction of apoptosis in cerebellar granule neurons by low potassium: inhibition of death by insulin-like growth factor I and cAMP. Proc Natl Acad Sci USA 90:10989-10993, 1993

19. European Study Group on Nimodipine in Severe Head Injury: A multicenter trial of the efficacy of nimodipine on outcome after severe head injury. J Neurosurg 80:797-804, 1994

20. Faden AI: Pharmacologic treatment of acute traumatic brain injury. JAMA 276:569-570, 1996 (Editorial)

21. Fleming RYD, Rutan RL, Jahoor F, et al: Effect of recombinant human growth hormone on catabolic hormones and free fatty acids following thermal injury. J Trauma 32:698-703, 1992

22. Florini JR: Hormonal control of muscle growth. Muscle Nerve 10:577-598, 1987

23. Frank HJL, Pardridge WM, Morris WL, et al: Binding and internalization of insulin and insulin-like growth factors by isolated brain microvessels. Diabetes 35:654-661, 1986

24. Fruin AH, Taylon C, Pettis MS: Caloric requirements in patients with severe head injuries. Surg Neurol 25:25-28, 1986

25. Garcia-Estrada J, Garcia-Segura LM, Torres-Aleman I: Expression of insulin-like growth factor I by astrocytes in response to injury. Brain Res 592:343-347, 1992 
26. Gluckman P, Klempt N, Guan J, et al: A role for IGF-1 in the rescue of CNS neurons following hypoxic-ischemic injury. Biochem Biophys Res Commun 182:593-599, 1992

27. Gottardis M, Nigitisch C, Schmutzhard E, et al: The secretion of human growth hormone stimulated by human growth hormone releasing factor following severe cranio-cerebral trauma. Intensive Care Med 16:163-166, 1990

28. Guan J, Williams C, Gunning M, et al: The effects of IGF-1 treatment after hypoxic-ischemic brain injury in adult rats. J Cereb Blood Flow Metab 13:609-616, 1993

29. Guler HP, Zapf J, Froesch ER: Short-term metabolic effects of recombinant human insulin-like growth factor I in healthy adults. N Engl J Med 317:137-140, 1987

30. Guler HP, Zapf J, Schmid C, et al: Insulin-like growth factors I and II in healthy man. Estimations of half-lives and production rates. Acta Endocrinol 121:753-758, 1989

31. Guyda HJ: Concepts of IGF physiology, in Spencer EM (ed): Modern Concepts of Insulin-like Growth Factors. Proceedings of the Second International Symposium on Insulin-Like Growth Factors/Somatomedins held January 12-16, 1991, in San Francisco, California. New York: Elsevier, 1991, pp 99-109

32. Harris JA, Benedict GF: A Biometric Study of Basal Metabolism in Man. Publication No. 279. Washington, DC: Carnegie Institute, 1919

33. Jacob V, Le Carpentier JE, Salzano S, et al: IGF-I, a marker of undernutrition in hemodialysis patients. Am J Clin Nutr 52:39-44, 1990

34. Jennett B, Bond M: Assessment of outcome after severe brain damage. A practical scale. Lancet 1:480-484, 1975

35. Jiang ZM, He GZ, Zhang SY, et al: Low-dose growth hormone and hypocaloric nutrition attenuate the protein-catabolic response after major operation. Ann Surg 210:513-525, 1989

36. Kupfer SR, Underwood LE, Baxter RC, et al: Enhancement of the anabolic effects of growth hormone and insulin-like growth factor I by use of both agents simultaneously. J Clin Invest 91:391-396, 1993

37. Lehmann S, Cerra FB: Growth hormone and nutritional support: adverse metabolic effects. Nutr Clin Pract 7:27-30, 1992

38. Lieberman SA, Bukar J, Chen SA, et al: Effects of recombinant human insulin-like growth factor-I (rhIGF-I) on total and free IGF-I concentrations, IGF-binding proteins, and glycemic response in humans. J Clin Endocrinol Metab 75:30-36, 1992

39. Lieberman SA, Butterfield GE, Harrison D, et al: Anabolic effects of recombinant insulin-like growth factor-I in cachectic patients with the acquired immunodeficiency syndrome. J Clin Endocrinol Metab 78:404-410, 1994

40. Marie C, Bralet J: Blood glucose level and morphological brain damage following cerebral ischemia. Cerebrovasc Brain Metab Rev 3:29-38, 1991 
41. Marshall LF, Marshall SB: Pitfalls and advances from the international tirilazad trial in moderate and severe head injury. J Neurotrauma 12:929-932, 1995

42. Masters BA, Raizada MK: Insulin-like growth factor I receptors and IGF-I actions in neuronal cultures from the brain. Ann NY Acad Sci 692:89-101, 1993

43. McClain C, Cohen D, Phillips R, et al: Increased plasma and ventricular fluid interleukin-6 levels in patients with head injury. J Lab Clin Med 118:225-231, 1991

44. McClain CJ, Cohen D, Ott L, et al: Ventricular fluid interleukin-1 in patients with head injury. J Lab Clin Med 110:48-54, 1987

45. McClain CJ, Hennig B, Ott LG, et al: Mechanisms and implications of hypoalbuminemia in head-injured patients. J Neurosurg 69:386-392, 1988

46. Minuto F, Barreca A, Adami GF, et al: Insulin-like growth factor-I in human malnutrition: relationship with some body composition and nutritional parameters. JPEN J Parenter Enteral Nutr 13:392-396, 1989

47. Moore R, Najarian MP, Konvolinka CW: Measured energy expenditure in severe head trauma. J Trauma 29:1633-1636, 1989

48. Muizelaar JP, Marmarou A, Young HG, et al: Improving the outcome of severe head injury with the oxygen radical scavenger polyethylene glycol conjugated superoxide dismutase: a phase II trial. J Neurosurg 78:375-382, 1993

49. Pardridge WM: Receptor-mediated peptide transport through the blood-brain barrier. Endocr Rev 7:314-330, 1986

50. Piccolboni D, de Vincentiis L, Guerriero G, et al: Nutritional and hormonal effects of biosynthetic human growth hormone in surgical patients on total parenteral nutrition. Nutrition 7:177-184, 1991

51. Quattrocchi KB, Frank EH, Miller CH, et al: Suppression of cellular immune activity following severe head injury. J Neurotrauma 7:77-87, 1990

52. Rapp RP, Young B, Twyman D, et al: The favorable effect of early parenteral feeding on survival in head-injured patients. J Neurosurg 58:906-912, 1983

53. Recio-Pinto E, Ishii DN: Insulin and related growth factors: effects on the nervous system and mechanism for neurite growth and regeneration. Neurochem Intern 12:397-414, 1988

54. Robertson C, Clifton GL, Grossman RG, et al: Alterations in cerebral availability of metabolic substrate after severe head injury. J Trauma 28:1523-1532, 1988

55. Roth E, Valentini L, Semsroth M, et al: Resistance of nitrogen metabolism to growth hormone treatment in the early phase after injury of patients with multiple injuries. J Trauma 38:136-141, 1995

56. Sandberg-Nordqvist AC, Ståhlbom PA, Lake M, et al: Characterization of two cDNAs encoding insulin-like growth factor 1 (IGF-1) in the human fetal brain. Brain Res Mol Brain Res 12:275-277, 1992

57. Teasdale G, Jennett B: Assessment of coma and impaired consciousness. A practical scale. Lancet 
2:81-84, 1974

58. Waters DC, Dechert R, Bartlett R: Metabolic studies in head injury patients: a preliminary report. Surgery 100:531-534, 1986

59. Wilmore DW: Catabolic illness. Strategies for enhancing recovery. N Engl J Med 325:695-702, 1991

60. Wilmore DW, Moylan JA Jr, Bristow BF, et al: Anabolic effects of human growth hormone and high caloric feedings following thermal injury. Surg Gynecol Obstet 138:875-884, 1974

61. Young AB, Ott LG, Beard D, et al: The acute-phase response of the brain-injured patient. J Neurosurg 69:375-380, 1988

62. Young B, Ott L, Dempsey R, et al: Relationship between admission hyperglycemia and neurologic outcome of severely brain-injured patients. Ann Surg 210:466-473, 1989

63. Young B, Ott L, Norton J, et al: Metabolic and nutritional sequelae in the non-steroid treated head injury patient. Neurosurgery 17:784-791, 1985

64. Young B, Ott L, Twyman D, et al: The effect of nutritional support on outcome from severe head injury. J Neurosurg 67:668-676, 1987

65. Young B, Runge JW, Waxman KS, et al: Effects of pegorgotein on neurologic outcome of patients with severe head injury. A multicenter, randomized controlled trial. JAMA 276:538-543, 1996

66. Ziegler TR, Young LS, Ferrari-Baliviera E, et al: Use of human growth hormone combined with nutritional support in a critical care unit. JPEN J Parenter Enteral Nutr 14:574-581, 1990

Manuscript received June 18, 1996.

Accepted in final form December 20, 1996.

This project was supported by Genentech Protocol No. F0186g and by National Institutes of Health Grant No. M01RR02602.

Address reprint requests to: Jimmi Hatton, Pharm.D., Department of Pharmacy, C-117, University of Kentucky Chandler Medical Center, 800 Rose Street, Lexington, Kentucky 40536-0084.

Click here to view Commentary on this Clinical Pearl. 